\title{
Penerapan LKS Model Pembelajaran Berbasis Masalah Untuk Meningkatkan Kemampuan Berpikir Tingkat Tinggi SMPN 5 Tondano
}

\author{
${ }^{1}$ Meike Paat, ${ }^{2}$ Femmy Roosje Kawuwung, ${ }^{3}$ Yohanes Bery Mokalu \\ Fakultas Matematika dan Ilmu Pengetahuan Alam, Universitas Negeri Manado \\ Email Korespondensi: meikepaat@unima.ac.id
}

\begin{abstract}
Abstrak. Penelitian ini bertujuan untuk meningkatkan kemampuan berpikir tingkat tinggi dan hasil belajar siswa pada mata pelajaran IPA Biologi materi sistem pencernaan manusia dengan menerapkan LKS model pembelajaran berbasis masalah pada siswa kelas VIII SMP Negeri 5 Tondano. Kurangnya kemampuan siswa dalam berpikir, memahami dan memecahkan masalah mengakibatkan rendahnya hasil belajar dan kemampuan berpikir tingkat tinggi siswa. Penelitian ini adalah penelitian tindakan kelas, dengan subjek penelitian yaitu 20 siswa kelas VIII SMP Negeri 5 Tondano. Metode penelitian yang digunakan yaitu penelitian tindakan kelas melalui dua siklus pembelajaran dengan empat tahapan yaitu perencanaan, tindakan, observasi, dan refleksi. Data dianalisis dengan rumus $\mathrm{P}=$ $\frac{F}{N} X 100 \%$. Hasil analisis data menunjukkan ada peningkatan hasil belajar dan kemampuan berpikir tingkat tinggi melalui penerapan model pembelajaran berbasis masalah. Peningkatan hasil belajar dan kemampuan berpikir tingkat tinggi dapat dilihat dari bertambahnya persentase hasil belajar dari setiap siklus, ketuntasan klasikal setiap siklus dan pertambahan jumlah siswa yang memenuhi Kriteria Ketuntasan Minimal. Peningkatan persentase hasil belajar siklus I sampai siklus II adalah dari 45\% (siklus I) menjadi 95\% pada siklus II. Jumlah siswa yang memenuhi Kriteria Ketuntasan Minimal yaitu pada siklus I berjumlah 9 siswa menjadi 19 siswa pada siklus II. Selisih peningkatan persentase hasil belajar dari siklus I ke siklus II sebesar 50\%. Dapat disimpulkan bahwa melalui penerapan model pembelajaran berbasis masalah dapat meningkatkan hasil belajar IPA Biologi serta kemampuan berpikir tingkat tinggi siswa.
\end{abstract}

Kata kunci: Pembelajaran Berbasis Masalah, Kemampuan Berpikir Tingkat Tinggi, LKS

Abstract. This study aims to improve high-order thinking skills and student learning outcomes in the subject of science biology human digestive system material by applying a problem-based learning to grade VIII students of SMPN 5 Tondano. Lack of students' ability to think, understand and solve problems results in low learning outcomes and students' higher-order thinking skills. This research is a classroom action research, the research subjects, 20 students of class VIII SMP Negeri 5 Tondano. The research method used is classroom action research through two learning cycles with the stages of planning, action, observation, and reflection. Data were analyzed using the formula $\mathrm{P}=\frac{F}{N} X 100 \%$. The results of data analysis show that there is an increase in learning outcomes and higher-order thinking skills through the application of problem-based learning models. The increase in learning outcomes and higher-order thinking skills can be seen from the increase of learning outcomes from each cycle, the classical completeness of each cycle, and the increase in the number of students who meet the minimum completeness criteria. The increase in the percentage of learning outcomes in cycle I to cycle II was from 45\% (cycle I) to 95\% (cycle II). The number of students who met the Minimum Completeness Criteria, namely in the first cycle is 9 students to 19 students in the second cycle. The increase in the percentage of learning outcomes from cycle I to cycle II by 50\%. It can be concluded that the application of problembased learning models can improve high-order thinking skills and student learning outcomes of science biology.

Keywords: Problem-Based Learning, Higher-Order Thinking Skills, Student Worksheet

\section{PENDAHULUAN}

Inovasi dalam bidang pendidikan adalah langkah awal untuk meningkatkan profesionalitas dalam sistem pembelajaran
(Siregar, 2019). Dalam proses pembelajaran guru diharapkan mampu berinovasi dalam menerapkan proses pembelajaran yang efektif, efisien, menyenangkan dan mampu 
memotivasi siswa (Paat, 2018) dengan cara mengaplikasikan suatu model pembelajaran yang relevan untuk membantu dan memfasilitasi serta memudahkan siswa dalam menguasai konsep yang dapat menunjang dan meningkatkan motivasi siswa untuk memahami pelajaran, meningkatkan kemampuan berpikir tingkat tinggi serta meningkatkan hasil belajar siswa. ketercapaian tujuan pendidikan sangat tergantung kepada pelaksanaan proses pembelajaran, keterampilan, dan pemilihan model pembelajaran. serta mampu menciptakan situasi dan kondisi dimana siswa membentuk makna dari pelajaran dengan menggunakan model pembelajaran yang tepat, serta sesuai dengan kebutuhan dan standar yang berlaku (Nurhayati, 2019).

Pembelajaran berkontribusi terhadap adaptasi untuk mengembangkan proses yang logis, sehingga perkembangan tingkah laku adalah hasil dari efek belajar. belajar itu bukan proses tunggal. Hasil belajar merupakan kapabilitas. Setelah belajar, orang memiliki keterampilan, pengetahuan, sikap dan nilai. Timbulnya kapabilitas tersebut berasal dari (1) stimulasi yang muncul dari lingkungan; (2) proses kognitif yang dilakukan siswa. Dengan demikian, belajar adalah seperangkat proses kognitif yang mengubah sifat stimulasi lingkungan, melewati pengolahan informasi menjadi kapabilitas baru. Juga dikemukakan bahwa belajar merupakan faktor yang luas yang dibentuk oleh pertumbuhan, perkembangan dan tingkah laku merupakan hasil dari aspek kumulatif belajar. Berdasarkan pandangan ini Gagne mendefinisikan pengertian belajar sebagai perubahan dalam disposisi atau kapabilitas manusia yang berlangsung selama satu masa waktu dan tidak disebabkan oleh proses pertumbuhan. Perubahan itu berbentuk perubahan tingkah laku. Hal itu dapat diketahui dengan jalan membandingkan tingkah laku sebelum belajar dan tingkah laku yang diperoleh setelah belajar. Perubahan tingkah laku dapat berbentuk perubahan kapabilitas jenis kerja atau perubahan sikap, minat atau nilai. (Gagne, dikutip Paat 2013).
Lembar Kerja Siswa (LKS) adalah suatu hal yang dibuat untuk menunjang dan memaksimalkan proses kegiatan pembelajaran di dunia pendidikan. (Fannie, 2014) dan juga sebagai pedoman bagi siswa dan digunakan untuk melakukan kegiatan belajar, penyelidikan, berpikir dan pemecahan masalah. Penerapan LKS dapat memberikan kegiatan pembelajaran yang terencana dengan baik dan mandiri. LKS merupakan panduan dalam melaksanakan pembelajaran. Fungsi dari LKS adalah: sebagai panduan siswa, dalam melakukan kegiatan belajar, lembar pengamatan, lembar diskusi, lembar penemuan, wahana untuk melati siswa lebih sistematis, berwarna bergambar, dan menarik perhatian siswa.

LKS merupakan media cetak yang dikembangkan dari teknologi cetak berupa materi visual dan buku. Penggunaan LKS yang baik dan menarik diharapkan dapat memaksimalkan minat dan motivasi siswa dalam belajar, LKS juga merupakan alat komunikasi yang bersifat menyampaikan pesan dan informasi serta mampu merangsang perasaan, pikiran, perilaku dan kemampuan serta keterampilan siswa sehingga mampu merangsang terjadinya proses pembelajaran yang maksimal, efektif dan efisien (Kembuan, 2020)

Pembelajaran dengan model

Pembelajaran Berbasis Masalah (PBM) melibatkan siswa secara aktif dalam memahami konsep dan prinsip dari suatu materi karena karakteristik pembelajaran iniberupa pengajuan masalah kepada siswa. Masalah yang diberikan dapat melatih siswa dalam melakukan kebiasaan memecahkan masalah yang akan berpengaruh kepada kemampuan tingkat tinggi siswa. Kemampuan yang dimaksud misalnya membiasakan siswa untuk berpikir kreatif dengan mengeksplorasi dan mengemukakan ide-ide, serta mengidentifikasi pemecahan masalah yang dapat diterapkan untuk menyelesaikan masalah yang diberikan. PBM merupakan model pembelajaran yang memberikan peluang bagi siswa menggali pengalaman autentik sehingga mendorong mereka aktif belajar, mengkonstruksi 
pengetahuan, dan mengintegrasikan konteks belajar di sekolah dan kehidupan nyata secara ilmiah. Siswa tidak sekedar mendengarkan, mencatat, dan menghafal materi yang disampaikan oleh guru, tetapi diharapkan mampu berfikir, mencari, mengolah data, dan berkomunikasi dalam proses pembelajaran. Model pembelajaran PBM hanya bisa terlaksana jika guru mampu menciptakan lingkungan belajar yang terbuka dan menuntun pertukaran gagasan. Peran guru adalah sebagai pemberi rangsangan, pembimbing kegiatan siswa, dan penentu arah belajar yaitu suatu pola atau kerangka konseptual yang berisi prosedur sistematik dalam mengorganisasikan kegiatan pembelajaran untuk mencapai tujuan pembelajaran (Fathurrohman, 2015). PBM menolong siswa untuk mengembangkan dan memaksimalkan keterampilan berpikir dan keterampilan mengatasi masalah, menjadi pelajar yang mandiri (Arends, 2012) dengan model PBM yang bersifat mengeksplorasi aktivitas dan keterampilan siswa terhadap konsep-konsep IPA dan sangat penting dalam menunjang peningkatan kinerja, kemampuan berpikir serta memecahkan permasalahan saat siswa mengikuti proses pembelajaran. Model PBM menumbuhkan kembangkan kemampuan siswa dalam mengidentifikasi masalah, kemampuan menyimpulkan hasil serta ketrampilan mengelola waktu. Model ini juga menambah pemahaman dan ketrampilan siswa dalam menyampaikan pendapat dan gagasangagasannya di depan kelas. Hal ini didukung penelitian sebelumnya yang dilakukan oleh Susilawati mendapatkan bahwa penggunaan model PBM mengajak siswa agar mampu melatih kemampuan siswa dalam memecahkan permasalahan sehingga dapat meningkatkan kemampuan berpikir kritis siswa (Susilawati, 2017). Melalui PBM para siswa akan belajar bagaimana menggunakan suatu proses interaktif memberikan kesempatan siswa untuk mengembangkan kemampuan psikomotornya yang berkaitan dengan ketrampilan berkomunikasi, representasi, pemodelan, dan penalaran.
Ketrampilan tersebut didapatkan melalui kegiatan melihat, mengamati, menanya, mencoba, menalar, menyaji, dan mencipta yang kesemuanya itu merupakan suatu proses yang terdapat pada pendekatan saintifik untuk meningkatkan keberagaman kemampuan berfikir analitis serta kepedulian pada lingkungan (Priadi, 2012). Model PBM menempatkan siswa sebagai pemikir aktif dalam memperoleh pengetahuan melalui pemecahan masalah dari pengalaman nyata. Peningkatan kemampuan memecahkan masalah dan hasil belajar kognitif siswa melalui pembelajaran dengan model PBM juga diduga karena model PBM didasarkan pada prinsip bahwa siswa tidak hanya memperoleh pengetahuan tetapi juga bahwa mereka tahu bagaimana menerapkan pengetahuan ini dalam situasi nyata, serta memiliki kemampuan dalam berpikir tingkat tinggi (Markus dan Hendrikus, 2016)

Berpikir tingkat tinggi adalah kemampuan berpikir yang menempati bagian atas pada taksonomi kognitif Bloom, serta kemampuan yang tujuan pengajarannya di balik taksonomi kognitif dapat membekali siswa dalam melaksanakan transfer ilmu pengetahuan yang juga merupakan bagian dari kemampuan berpikir agar dapat menerapkan pengetahuan dan keterampilan yang dikembangkan selama belajar pada konteks yang baru (Nurhayati, 2017). Keterampilan dalam berpikir tingkat tinggi adalah suatu kemampuan berpikir kompleks yang memerlukan keterampilanketerampilan lain yang lebih tinggi, seperti kemampuan berpikir, menganalisis, mengevaluasi, dan mencipta, Salah satu keterampilan berpikir adalah keterampilan berpikir tingkat tinggi (higher order thinking skills) untuk menuntun siswa beradaptasi di dunia nyata, menjadi pemikir kritis, inovatif dan juga kreatif, pemecah masalah sekaligus pemimpin dan pengambil keputusan (Angraini, 2019).

PBM adalah kurikulum dan proses pembelajaran yang dalamnya disusun masalah-masalah yang menuntut siswa menggapai pengetahuan esensial, meningkatkan kemahiran mereka dalam 
memecahkan permasalahan yang ada, dan memiliki strategi belajar sendiri serta memiliki kemampuan dalam berpikir tingkat tinggi sekaligus kemampuan berpartisipasi dalam tim. Proses pembelajarannya menggunakan pendekatan yang sistematis untuk memecahkan masalah atau menghadapi tantangan yang nanti diperlukan dalam karier dan kehidupan sehari-hari. Dalam penelitian pengembangan yang dilakukan oleh Sumarmin Modul Biologi dengan LKS yang berorientasi pada model PBM sangat efektif, hal ini dapat dilihat dari aktifitas, motivasi dan hasil belajar siswa (Sumarmin, 2018).

Tujuan dari penelitian ini untuk menerapkan LKS model pembelajaran pembelajaran berbasis masalah untuk meningkatkan kemampuan berpikir tingkat tinggi siswa kelas VIII SMP Negeri 5 Tondano khususnya pada materi sistem pencernaan.

\section{METODE PENELITIAN}

Penelitian ini dilaksanakan di SMP Negeri 5 Tondano, dengan subyek penelitian adalah siswa kelas VIII berjumlah 20 siswa. Penelitian ini dilaksanakan pada semester genap 2020, sebelum melaksanakan tahapan peneltian, peneliti mengadakan penelitian pendahuluan untuk mengetahui permasalahan yang ada dengan mewawancarai guru dan siswa.

Tahapan yang dilaksanakan pada penelitian ini:

1. Penelitian pendahuluan

Mengetahui permasalahan dan kebutuhan yang ada di Kelas VIII SMPN 5 Tondano

2. Perencanaan

1) Menyusun RPP

2) Menyiapkan instrument penelitian untuk guru dan siswa

3) Menyiapkan sumber belajar berupa materi pembelajaran dan LKS

4) Mengembangkan langkah-langkah pembelajaran dengan Model Pembelajaran Berbasis Masalah

5) Membuat soal-soal tes yang berisi soal-soal C4, C5, C6 untuk mengukur kemampuan berpikir tingkat tinggi

3. Tindakan

Menerapkan tindakan yang mengacu pada rencana pelaksanaan pembelajaran dengan menggunakan model Pembelajaran Berbasis Masalah

4. Pengamatan/observasi

Menilai hasil tindakan dengan menggunakan lembar observasi yang diberikan kepada siswa

5. Refleksi

1) Melakukan evaluasi pada tindakan siklus I berdasarkan data yang terkumpul.

2) Membahasa hasil evaluasi terhadap tindakan pembelajaran pada silkus I.

3) Jika masih ada masalah, misalnya masih ada banyak (>50\%) siswa yang kurang atau belum mengerti materi yang diajarkan, maka akan dilanjutkan pada siklus selanjutnya tapi jika tidak ada lagi permasalahan akan berhenti pada siklus tersebut atau selesai. (Amien, dikutip oleh Paat, 2013)

$$
\mathrm{P}=\frac{F}{N} X 100 \%
$$

Rumus persentase (Arikunto, 2019)

\section{HASIL DAN PEMBAHASAN}

Penelitian ini dilaksanakan di SMP Negeri 5 Tondano, dengan subyek penelitian yaitu siswa kelas VIII yang berjumlah 20 orang.

1. Hasil Penelitian Siklus I

Penelitian siklus pertama menggunakan bahan ajar dan LKS (Lembar Kerja Siswa) yang disusun sendiri oleh peneliti sebagai media pembelajaran dan mengukur sejauhmana keaktifan/kreatifitas siswa dalam proses pembelajaran serta mengukur kemampuan berpikir tingkat tinggi siswa dengan menggunakan soal C5 dan C6. 


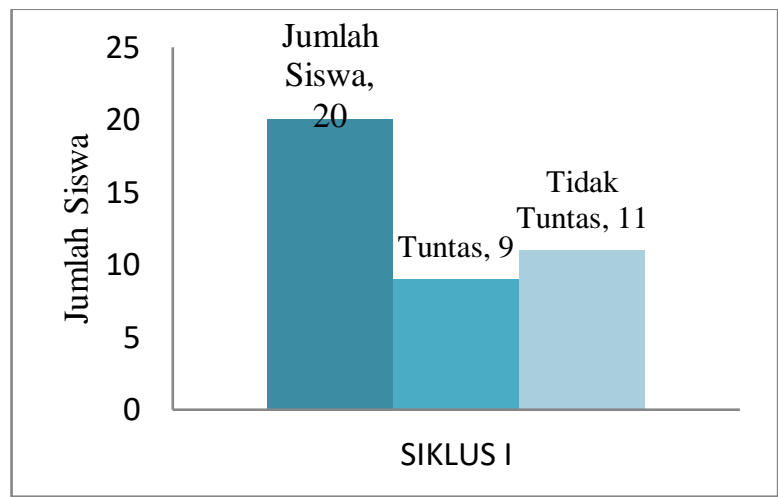

Gambar 1. Siklus I

Pada siklus pertama, pelaksanaan tindakan diadakan tes dibagian akhir dengan persentase secara klasikal hanya mencapai $45 \%$ atau hanya 9 siswa saja yang tuntas belajar. Secara individu terdapat 11 atau $55 \%$ siswa belum mencapai ketuntasan belajar klasikal yaitu 75. Melihat kenyataan tersebut maka peneliti melanjutkan tahap penelitian tindakan ke siklus dua.

\section{Hasil Penelitian Siklus ke Dua}

Pada siklus ke dua ini, identifikasi masalah dilaksanakan oleh peneliti pada silkus pertama dengan mengacu pada lembar observasi siklus pertama dan masukan dari observer, kemudian peneliti melakukan pendekatan, memotivasi serta memfasilitasi siswa yang mengalami gangguan dalam belajar seperti; tidak fokus/konsentrasi, malas, kurang memahami dan terbiasa dengan model Pembelajaran Berbasis Masalah dan lain-lain selama proses pembelajaran berlangsung. Pada pelaksanaan tindakan siklus ke dua ini, peneliti juga menggunakan bahan ajar dan LKS yang juga disusun sendiri oleh peneliti berdasarkan sintaks model Pembelajaran Berbasis Masalah serta panduan pelaksanaannya sebagai media pembelajaran.

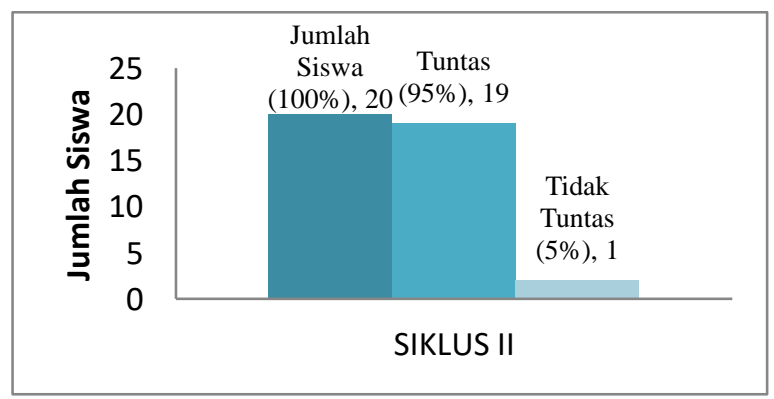

Gambar 2. Siklus II
Hasil analisis evaluasi belajar yang dilaksanakan di siklus ke dua ini diperoleh 95\% siswa telah mencapai nilai ketuntasan belajar secara klasikal dan hanya tinggal 1 siswa yang belum tuntas karena siswa tersebut sakit dan tidak mengikuti tes. Berdasarkan hasil evaluasi pada siklus kedua ini, maka peneliti tidak lagi melanjutkan penelitian ke siklus selanjutnya.

\section{Pembahasan}

Hasil analisis evaluasi proses pembelajaran sampai akhir dengan penerapan model Pembelajaran Berbasis Masalah untuk meningkatkan kemampuan berpikir tingkat tinggi siswa yang diterapkan pada siklus pertama persentase belajar secara klasikal mencapai $45 \%$ artinya ada 9 siswa yang tuntas, sedangkan 11 siswa belum mencapai nilai ketuntasan. Berdasarkan hasil evaluasi pada siklus pertama, maka peneliti melanjutkan penelitian pada siklus II. Pada siklus ke dua ini peneliti mengidentifikasi masalah-masalah pada siklus I dimana tedapat siswa yang belum terbiasa dengan penerapan model pembelajaran berbasis masalah dan siswa yang kurang berkonsentrasi/fokus dalam mengerjakan LKS. Melalui hasil identifikasi tersebut, pada siklus ke dua sebelum membuka pembelajaran peneliti terlebih dahulu memberikan petunjuk dan mengarahkan siswa dalam mengerjakan LKS, memberikan beberapa pendekatan, motivasi dan dorongan kepada siswa agar lebih berkonsentrasi, besemangat, kreatif dan berpartisipasi aktif dalam mengikuti proses pembelajaran. Peneliti melihat ada peningkatan baik dalam proses pembelajaran maupun tes akhir siklus.. Pada siklus ke dua ini hasil evaluasi menunjukkan peningkatan sebesar 50\% dari siklus I ke Siklus II dan telah mencapai standar nilai ketuntasan klasikal dengan persentase akhir sebesar 95\% artinya dari 20 siswa terdapat 19 siswa yang mengikuti tes dan semua siswa yang mengikuti tes mencapai nilai ketuntasan belajar klasikal, tapi secara individu masih ada 1 siswa yang belum mencapai nilai ketuntasan klasikal dikarenakan siswa tersebut sakit dan tidak mengikuti tes. dengan demikian peneliti 
tidak lagi melanjutkan penelitian ke siklus berikutnya sebab hasil tes telah melebihi standar nilai ketuntasan klasikal yaitu $75 \%$. Selain itu peneliti juga mengevaluaisi kegiatan pembelajaran siswa melalui LKS.

LKS mempunyai fungsi sebagai media dalam kegiatan pembelajaran. Khususnya lembar kerja siswa berstruktur kegunaannnya da;lam pembelajaran biologi antara lain: (1) Merupakan alternative bagi guru untuk mengarahkan pembelajaran atau memperkenalkan suatu kegiatan seperti pengenalan fakta, skill, konsep dan prinsip sebagai variasi menghajar, (2) Mempercepat proses pembelajaran sehingga dapat menghemat waktu pembelajaran, (3) Memudahkan penyesuaian tugas perorangan/kelompok, (4) Meringankan kerja guru dalam memberi bantuan perorangan atau meremidi terutama pengelolaan kelas besar, (5) Mengoptimalkan penggunaan media pembelajaran yang terbatas. (Paat. 2013). LKS merupakan salah satu sumber belajar yang membantu siswa unhuk mengembangkan pengetahuan yang telah dimiliki dalam penguasaan materi, permasalahan, kreatif dan aktif mencari pemecahan masalah/solusi, membantu siswa belajar berkelompok dan mandiri, serta meningkatkan kemampuan berpikir tingkat tinggi siswa dengan menggunakan soal-soal C4, C5 dan C6 (Mayasari, 2016).

\begin{tabular}{lccr}
\multicolumn{2}{c}{ Model Pembelajaran } & Berbasis \\
Masalah merupakan satu & strategi \\
pembelajaran, yakni & satu & solusi \\
pembelajaran yang dirancang & untuk \\
meningkatkan belajar dengan & cara \\
mengantar membawa, menuntun & dan
\end{tabular}
mempersyaratkan siswa agar mempelajari konten materi ajar saat menyelesaikan masalah. (Paat, 2013). Pembelajaran Berbasis Masalah dalam IPA biologi dilakukan dengan cara menyajikan suatu permasalahan, mengajukan pertanyaanpertanyaan, memfasilitasi penyelidikan, dan membuka dialog. Permasalahan harus dipecahkan dengan menerapkan berbagai prinsip dan konsep yang secara simultan yang tercakup dalam kurikulum mata pelajaran. Sebuah permasalahan pada umumnya dapat diselesaikan dalam beberapa kali pertemuan, karena merupakan permasalahan multikonsep bahkan dapat merupakan masalah multidisiplin ilmu karena Pembelajaran Berbasis Masalah merupakan suatu pendekatan pembelajaran yang menggunakan masalah nyata yang ada di dunia sebagai suatu konteks bagi siswa untuk belajar tentang cara berpikir tingkat tinggi dan keterampilan pemecahan masalah, serta untuk memperoleh pengetahuan dan konsep yang esensial dari materi yang diajarkan. Pembelajaran Berbasis Masalah merupakan pembelajaran yang berdasarkan teori kognitif, didalamnya termasuk teori belajar konstruktivisme. Menurut teori konstruktivisme, keterampilan berpikir dan memecahkan masalah dapat dikembangkan jika siswa melakukan sendiri, menemukan, membuat dan memindahkan kekomplekan pengetahuan yang ada (Yunin, 2014).

LKS Model Pembelajaran Berbasis Masalah yang diterapkan pada proses pembelajaran ternyata dapat membuat siswa menguasai materi pembelajaran baik dalam bidang kognitif, afektif maupun psikomotor, serta meningkatkan kemampuan berpikir tingkat tinggi siswa. Hal ini terlihat diakhir siklus dengan diadakan tes baik siklus pertama dan ke dua hasil belajar siswa meningkat dan tuntas, sementara ke 2 siswa yang tidak tuntas itu disebabkan oleh faktor seperti sakit dan lain-lain, hal ini sejalan dengan penelitian yang dilakukan oleh Yunin dan Wardan yang menunjukkan peningkatan penilaian pada aspek-aspek yang sebelumnya masih kurang dan peningkatan hasil belajar siswa pada siklus II terkait dengan semakin meningkatnya penguasaan siswa pada langkah-langkah perbaikan PC dengan menggunakan keterampilan berpikir kritis melalui penerapan Pembelajaran Berbasis Masalah (Yunin, 2014) dan diperkuat oleh penelitian dari Mely dkk yang menyatakan bahwa pembelajaran menggunakan model Pembelajaran Berbasis Masalah diperoleh pengaruh sebesar $31,82 \%$. Berdasarkan hasil penelitian dapat disimpulkan bahwa model 
Pembelajaran Berbasis Masalah berpengaruh terhadap peningkatan hasil belajar dan keterampilan proses sains siswa. (Mely, 2018). Dan dari hasil penelitian oleh Markus menyatakan bahwa rata-rata nilai terkoreksi dari dua model pembelajaran menunjukkan bahwa hasil kemampuan memecahkan masalah dengan model pembelajaran Pembelajaran Berbasis Masalah lebih tinggi daripada model pembelajaran konvensional karena Pembelajaran Berbasis Masalah melibatkan siswa aktif dalam pembelajaran biologi sehingga pembelajaran siswa menjadi lebih bermakna dan pembelajaran biologi dengan model Pembelajaran Berbasis Masalah juga memberikan keleluasaan siswa untuk berinteraksi antar sesama siswa dan antar guru dengan siswa. Hal ini berdampak pada rasa memiliki bahwa pembelajaran di kelas bukan hanya milik guru, namun juga milik siswa sehingga siswa akan terlatih untuk bertanggung jawab dalam belajarnya, Berdasarkan hasil penelitian ini pun dapat disimpulkan bahwa model Pembelajaran Berbasis Masalah secara signifikan meningkatkan kemampuan memecahkan masalah dan hasil belajar kognitif pada siswa. (Markus, 2016)

\section{KESIMPULAN}

Berdasarkan hasil perhitungan, analisis dan pembahasan yang telah dilakukan dalam penelitian ini dapat diambil kesimpulan sebagai berikut:

1. Implementasi LKS model Pembelajaran Berbasis Masalah dalam proses pembelajaran IPA biologi di SMPN 5 Tondano merupakan model yang menarik, menyenangkan serta tidak membosankan, sehingga dapat meningkatkan hasil belajar dan kemampuan berpikir tingkat tinggi siswa.

2. LKS model PBM yang diterapkan dalam proses pembelajaran IPA biologi dapat dikembangkan untuk pembelajaran IPA biologi lainnya karena sangat efektif dan efisien untuk pencapaian tujuan pembelajaran selama pertimbangan sarana prasarana, ketersediaan tutor, ketersedian sumber belajar dan faktor pendukung lainya terpenuhi.

\section{SARAN}

Melalui penelitian ini, kiranya bisa memberikan gambaran terkait penerapan model pembelajaran berbasis masalah untuk meningkatkan kemampuan berpikir tingkat tinggi. Namun, penelitian ini belum sempurna. Oleh karena itu, bagi para peneliti lainnya boleh kiranya mengembangkan penelitian ini karena masih banyak aspek yang belum dilihat terkait penerapan model pembelajaran berbasis masalah untuk meningkatkan kemampuan berpikir tingkat tinggi. Semoga penelitian ini dapat menjadi referensi untuk penelitian berikutnya.

\section{DAFTAR PUSTAKA}

Angraini, G., \& Sriyati, S. (2019). Analisis Kemampuan Berpikir Tingkat Tinggi Siswa SMAN Kelas X di Kota Solok pada Konten Biologi. Jurnal of Education Informatic Technology aand Science, 1(1), 114-124.

Arends, R. (2012). Learning to Teach. Ninth Edition. NewYork: McGrawHill

Arikunto, S. (2019). Prosedur Penelitian Edisi Revisi VI. Litbangkes

Fannie, R. D., \& Rohati, R. (2014). Pengembangan lembar kerja siswa (LKS) berbasis POE (predict, observe, explain) pada materi program linear kelas XII SMA. Sainmatika: Jurnal Sains dan Matematika Universitas Jambi, 8(1), 221053.

Fathurrohman, M. (2015). Model-Model Pembelajaran. Jogjakarta: Ar-Ruzz Media.

Kembuan, G., Tumbel, F., \& Paat, M. (2020). Pengembangan Lembar Kerja Siswa Berbasis Problem Based Learning Untuk Meningkatkan Hasil Belajar Siswa di SMP Negeri 1 Poigar. Dunia Edukasi Pendidikan IPA, 1(1), 2432.

Mayasari, R., \& Adawiyah, R. (2016). Pengaruh model pembelajaran 
berdasarkan masalah pada pembelajaran biologi terhadap hasil belajar dan keterampilan berpikir tingkat tinggi di SMA. JPBI (Jurnal Pendidikan Biologi Indonesia), 1(3).

Markus, I. S., Hendrikus J. (2016). Pengaruh Model Problem Based Learning (PBL) terhadap Kemampuan Memecahkan Masalah dan Hasil Belajar Kognitif Siswa Biologi SMA. Jurnal Pendidikan Sains, Volume 4, Nomor 2, Hal 60-64. UM. Malang

Mely, C. J., Antonius T. W., dan Kasmui. (2018). Pengaruh Model Problem Based Learning Terhadap Hasil Belajar dan Keterampilan Proses Sains. Jurnal Inovasi Pendidikan Kimia, Vol 12, No. 1, , hal 2097

Nurhayati, N., \& Angraeni, L. (2017). Analisis kemampuan berpikir tingkat tinggi mahasiswa (higher order thinking) dalam menyelesaikan soal konsep optika melalui model problem based learning. Jurnal Penelitian \& Pengembangan Pendidikan Fisika, 3(2), 119-126.

Nurhayati, N., Angraeni, L., \& Wahyudi, W. (2019). Pengaruh Model Problem Based Learning, Kemampuan Berpikir Kritis terhadap Kemampuan Berpikir Tingkat Tinggi. EDUSAINS, 11(1), 12-20.

Paat, M., (2013). Pengembangan Model Pembelajaran Berbasis Masalah Mata Pelajaran Biologi. Jurnal Teknologi Pendidikan, Vol. 14, No. 3. ISSN 1411-2744

Paat, M., Marentek, E. A., \& Pelenkahu, N. (2018). Problem-Based Instructional Development Model At Senior High School In Manado, North Sulawesi, Indonesia. Journal of Advanced Research in English \& Education, 3(4), 15-24.

Priadi, M.A., Sudarisman, S., \& Suparmi. (2012). Pembelajaran Biologi Menggunakan Model Problem
Based Learning Melalui Metode Eksperimen Laboratorium dan Lapangan Ditinjau dari Keberagaman Kemampuan Berfikir Analitis dan Sikap Peduli Lingkungan. Jurnal Inkuiri, 1(3):217-226.

Siregar, N., Sutopo, H., \& Paat, M. (2019). Mobile Multimedia-based Batakologi Learning Model Development. Journal of Mobile Multimedia, 271-288.

Sumarmin, R., Ayu, D. M., \& Lufri, L. (2018). The Development Of Biology Modul With LKS Orientation Problem Based Learning (PBL) In Topic Environmental Pollution For Grade X. Bioeducation Journal, 2(1), 7686.

Susilawati, S., Jamaluddin, J., \& Bachtiar, I. (2017). Pengaruh model pembelajaran berbasis masalah (PBM) berbantuan multimedia terhadap kemampuan berpikir kritis peserta didik kelas vii smp negeri 2 mataram ditinjau dari kemampuan akademik. Jurnal Mipa, 12(2), 64-70.

Pijar

Yunin, N. dan Wardan S. (2014). Penerapan Model Problem-Based Learning Untuk Meningkatkan Keterampilan Berpikir Kritis Dan Hasil Belajar Siswa. Jurnal Pendidikan Vokasi, Vol 4, Nomor 1 